Article

\title{
Revisiting the Karyotypes of Alligators and Caimans (Crocodylia, Alligatoridae) after a Half-Century Delay: Bridging the Gap in the Chromosomal Evolution of Reptiles
}

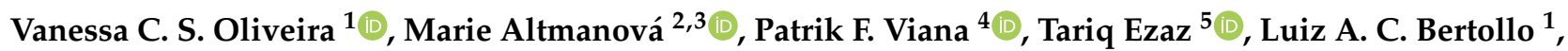 \\ Petr Ráb ${ }^{3}$, Thomas Liehr ${ }^{6, *}$,, Ahmed Al-Rikabi ${ }^{6}$, Eliana Feldberg ${ }^{4}$, Terumi Hatanaka ${ }^{1}$, Sebastian Scholz ${ }^{7}$,
} Alexander Meurer ${ }^{8}$ and Marcelo de Bello Cioffi ${ }^{1}{ }^{1}$

Citation: Oliveira, V.C.S.;

Altmanová, M.; Viana, P.F.; Ezaz, T.; Bertollo, L.A.C.; Ráb, P.; Liehr, T.;

Al-Rikabi, A.; Feldberg, E.; Hatanaka,

T.; et al. Revisiting the Karyotypes of

Alligators and Caimans (Crocodylia,

Alligatoridae) after a Half-Century

Delay: Bridging the Gap in the

Chromosomal Evolution of Reptiles.

Cells 2021, 10, 1397. https://doi.org/

$10.3390 /$ cells10061397

Academic Editor: Terje Raudsepp

Received: 11 May 2021

Accepted: 2 June 2021

Published: 5 June 2021

Publisher's Note: MDPI stays neutral with regard to jurisdictional claims in published maps and institutional affiliations.

Copyright: (c) 2021 by the authors. Licensee MDPI, Basel, Switzerland. This article is an open access article distributed under the terms and conditions of the Creative Commons Attribution (CC BY) license (https:// creativecommons.org/licenses/by/ $4.0 /)$.
1 Laboratório de Citogenética de Peixes, Departamento de Genética e Evolução, Universidade Federal de São Carlos, São Carlos 13565-905, Brazil; vanessacristina.sales@gmail.com (V.C.S.O.); bertollo@ufscar.br (L.A.C.B.); hterumi@yahoo.com.br (T.H.); mbcioffi@ufscar.br (M.d.B.C.)

2 Department of Ecology, Faculty of Science, Charles University, 12844 Prague, Czech Republic; altmanova.m@gmail.com

3 Laboratory of Fish Genetics, Institute of Animal Physiology and Genetics, Czech Academy of Sciences, 27721 Liběchov, Czech Republic; rab@iapg.cas.cz

4 Laboratório de Genética Animal, Coordenação de Biodiversidade, Instituto Nacional de Pesquisas da Amazônia, Manaus 69083-000, Brazil; patrik.biologia@gmail.com (P.F.V.); feldberg@inpa.gov.br (E.F.)

5 Institute for Applied Ecology, Faculty of Science and Technology, University of Canberra, Bruce, ACT 2617, Australia; tariq.ezaz@canberra.edu.au

6 Institute of Human Genetics, Jena University Hospital, Am Klinikum 1, 07747 Jena, Germany; ahmedgenetic@hotmail.com

7 An der Nachtweide 16, 60433 Frankfurt, Germany; chinemys@web.de

8 Alfred Nobel Strasse 1e, 55411 Bingen am Rhein, Germany; ameurer@online.de

* Correspondence: Thomas.Liehr@med.uni-jena.de; Tel.: +49-36-41-939-68-50; Fax: +49-3641-93-96-852

\begin{abstract}
Although crocodilians have attracted enormous attention in other research fields, from the cytogenetic point of view, this group remains understudied. Here, we analyzed the karyotypes of eight species formally described from the Alligatoridae family using differential staining, fluorescence in situ hybridization with rDNA and repetitive motifs as a probe, whole chromosome painting (WCP), and comparative genome hybridization. All Caimaninae species have a diploid chromosome number (2n) 42 and karyotypes dominated by acrocentric chromosomes, in contrast to both species of Alligatorinae, which have $2 n=32$ and karyotypes that are predominantly metacentric, suggesting fusion/fission rearrangements. Our WCP results supported this scenario by revealing the homeology of the largest metacentric pair present in both Alligator spp. with two smaller pairs of acrocentrics in Caimaninae species. The clusters of $18 \mathrm{~S}$ rDNA were found on one chromosome pair in all species, except for Paleosuchus spp., which possessed three chromosome pairs bearing these sites. Similarly, comparative genomic hybridization demonstrated an advanced stage of sequence divergence among the caiman genomes, with Paleosuchus standing out as the most divergent. Thus, although Alligatoridae exhibited rather low species diversity and some level of karyotype stasis, their genomic content indicates that they are not as conserved as previously thought. These new data deepen the discussion of cytotaxonomy in this family.
\end{abstract}

Keywords: Alligatoridae; cytogenomics; chromosome; molecular cytogenetics

\section{Introduction}

Unlike other vertebrates that underwent substantial diversification, extant crocodilian species have maintained morphological and ecological similarities for almost 100 million years (Myr) [1-4]. Crocodilians along with dinosaurs, pterosaurs, and birds form a monophyletic clade known as archosaurs. They represent a bridge between recent birds 
and non-avian recent reptiles; in support of this premise, the evidence from molecular phylogenetics indicates that crocodilians and birds form a monophyletic clade [5-8].

The order Crocodylia is a useful model for biogeographic studies, as its species show a circumtropical distribution, with at least one extant representative in each continent, except for Europe and Antarctica [9,10]. Such circum-oceanic distribution, combined with the ancient age and distinct phylogenetic position, make crocodilians an attractive model to understand evolutionary and biogeographic characteristics of ancient vertebrates, including the fact that they demonstrate the past dispersal events of many vertebrate lineages. Although their biogeography is still a mystery, some recent studies proposed that a relatively recent trans-Atlantic crossing, from Africa to the New World and from Indopacific to the New World likely occurred for certain crocodile species [4,11,12].

Crocodylia is divided into three families (Figure 1): Crocodylidae, Gavialidae, and Alligatoridae, and the number of currently described species ranges from 23 to 26 [2,13-20]. Crocodylidae is represented by three genera, namely Crocodylus, Mecistops, and Osteolaemus, and it is composed of 16 species [14,21] — but potentially reaching 17 depending on formal taxonomic review and species validation $[15,16,21,22]$. This family is distributed in Asia, Australia, Africa, and America [11]. Gavialidae has only one species, the Indian gharial Gavialis gangeticus, which is native to India and Nepal [23,24]. However, the phylogenetic position of the false gharial Tomistoma schlegelii, a species widespread in South Asia, remains under debate, although molecular analyses put Tomistoma into Gavialidae [8,12]. The third family, Alligatoridae, consists of eight species distributed in four genera: Alligator, forming the monogeneric subfamily Alligatorinae, and Melanosuchus, Paleosuchus, and Caiman, belonging to Caimaninae $[8,20]$ (but see $[25,26]$ suggesting the existence of other cryptic species). Except for Alligator, where A. mississippiensis and A. sinensis are restricted to the Southeastern United States and China, respectively, the distribution of Caimaninae species ranges from Mexico to South America, being especially widespread in Brazil [2,12]. Yet, e.g., Caiman crocodilus has been introduced also to other regions such as Puerto Rico, Cuba, and Florida [27]. A. sinensis represents one of the most endangered crocodilian species, listed as a CITES Appendix I species, in the category 'critically endangered' by the International Union for Conservation of Nature (IUCN). The most recent survey performed in 2015 indicated that its wild population was estimated at 136-173 individuals (32 adults) concentrated in a small region in southeastern Anhui Province [28] - a fraction of its former distribution [29].

Reptiles show a vast diversity in diploid chromosome number (2n) and karyotype morphology, with various combinations of macro- and microchromosomes, as well as sex determination systems [30-32]. Molecular cytogenetic techniques have been largely applied, providing better insight into their chromosomal evolution (reviewed in [31]). In addition to the mapping of repetitive DNA sequences and whole chromosome painting (WCP) experiments, the recent use of the comparative genomic hybridization (CGH) has allowed us to compare the degree of genome similarity at the level of repetitive DNA content among phylogenetically related species [33-42]. However, cytogenetic data for Crocodylia are usually restricted to the description of the $2 \mathrm{n}$, karyotype composition, and some conventional banding [43-46]; only few studies used molecular cytogenetic tools $[45,47-51]$.

The $2 \mathrm{n}$ of crocodilians ranges from 30 to 42 and positively correlates with the ratio of acrocentrics in the complement. Together with low variability in the number of chromosome arms, NF = 56-60/62 (NF, nombre fondamental), it suggests that the karyotypes evolved mostly by fusion/fission $[17,44,52]$. Their karyotype structure, however, lacks typical reptile dot-shaped microchromosomes. Such pattern strikingly contrasts with the one found in birds and turtles, once their karyotypes comprise, with few exceptions, at least 50 chromosomes including a small number of macrochromosomes and many indistinguishable microchromosomes [31,40,52,53]. 


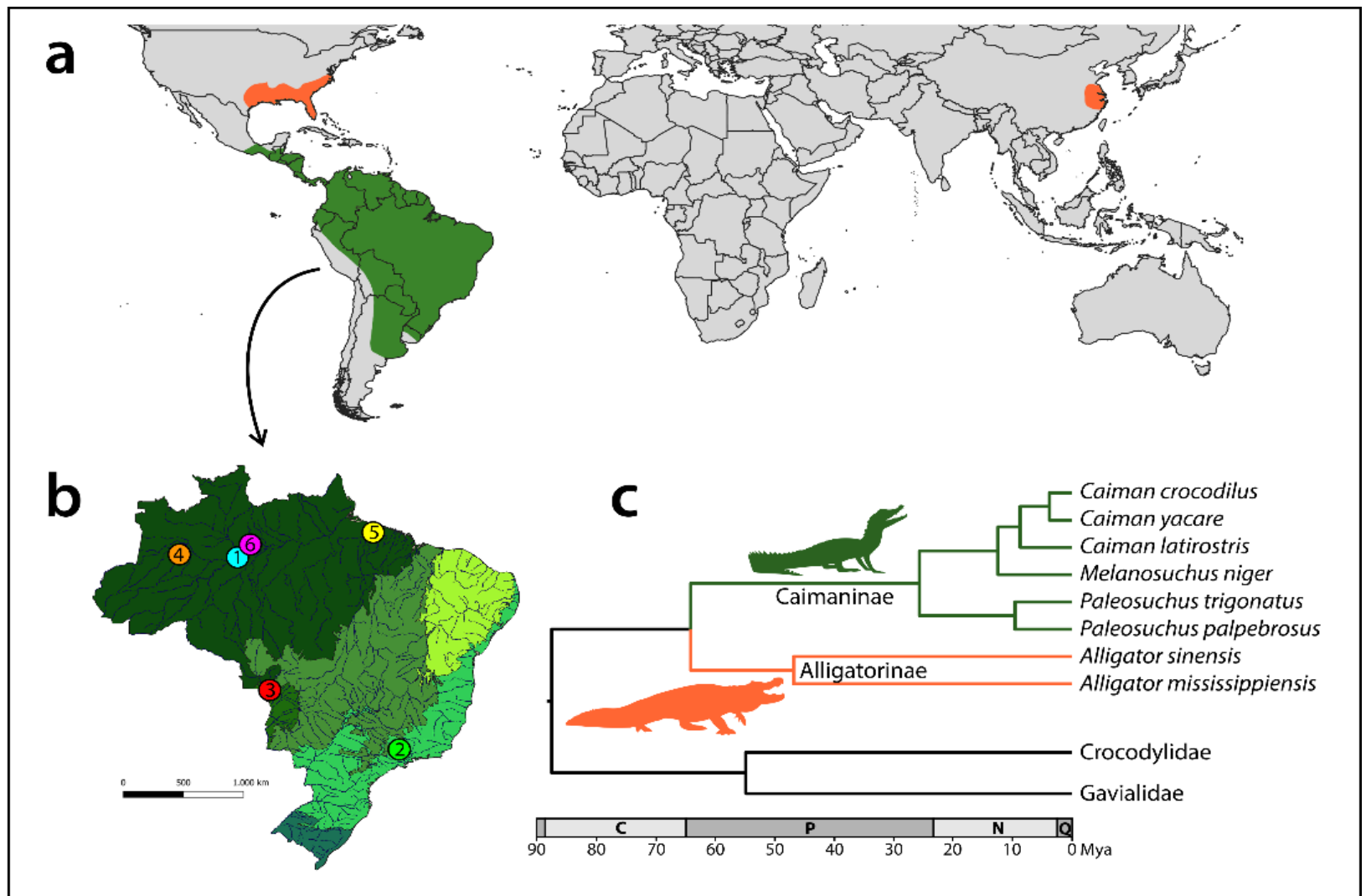

Figure 1. Recent distribution (a), sampling sites (b), and phylogenetic relationships (c) of Alligatoridae species. Map of Brazil highlighting the collection sites (colored circles) of the Caimaninae species analyzed in the present work, namely: 1. Caiman crocodilus (light blue circle); 2. Caiman latirostris (green circle); 3. Caiman yacare (red circle); 4 . Melanosuchus niger (orange circle); 5. Paleosuchus palpebrosus (yellow circle); and 6. Paleosuchus trigonatus (pink circle). The map was created using QGis 3.4.3 and Adobe Photoshop CC 2020 software. Adapted time-calibrated phylogenetic tree for the order Crocodylia, focusing on Alligatoridae, based on data generated by [12] for an alternative dating see [8]. C-Cretaceous, $\mathrm{P}$-Paleogene, $\mathrm{N}$-Neogene, Q-Quaternary, and Myr—million years ago.

In addition, the G-banding pattern is very conservative in Crocodylia, showing similar pattern among chromosomes of Crocodylus porosus, Crocodylus johnstoni, and Caiman crocodilus [45], pointing to a generally conserved chromosome/replication structure without apparent inter- or intra-chromosomal reshuffling among species. Another notable crocodilian feature is that the whole order likely shares the environmental sex determination (ESD). The effect of incubation temperature on the offspring sex ratio was observed in several species and on the other hand, the sex chromosomes have not been identified in any of cytogenetically studied species [35,44,54-56].

Thus, based mostly on conventional methods, the cytogenetics of Crocodylia still represents a kind of missing piece in understanding of chromosomal evolutionary patterns in reptiles. To fill this gap, we analyzed the karyotype organization of all taxonomically recognized Alligatoridae species by differential conventional stainings and up to date molecular cytogenetic techniques, namely the chromosomal mapping of repetitive DNA sequences, WCP, and CGH methods. The results are compared and discussed with previously published data. This study is part of a series on cytogenetics and cytogenomics of crocodilians.

\section{Materials and Methods}

\subsection{Sampling Species, Mitotic Chromosome Preparations, C-Banding, and CMA3 Staining}

Blood samples were obtained from free-living South American animals with the authorization of the environmental agency ICMBIO/SISBIO (License $n^{\circ}$ 71857-7) and 
SISGEN (ABFF266). Blood samples from Alligator sinensis came from the animals legally kept in Europe (CITES certificate number EU 0228-1057/14, ES-CC-00041/07C, ES-CC00036/07C, 50721-18, DE-DA190814-5, DE-DA190814-6). The collection sites, number, and sex of individuals are summarized in Figure 1 and Table 1 . All experiments followed ethical conduct and were approved by the Ethics Committee on Animal Experimentation of the Universidade Federal de São Carlos (Process number CEUA 4617090919). No animals were seriously harmed, and all free-living individuals were released back to their respective collection sites.

Table 1. Species, sample size (N), sex and locality of the analyzed individuals.

\begin{tabular}{|c|c|c|c|}
\hline Species & $\mathbf{N}$ & \multicolumn{2}{|c|}{ Locality/Origin of Samples } \\
\hline (1) Caiman crocodilus & $2 q, 20^{\pi}$ & Amazonas (BR) & $\begin{array}{l}3^{\circ} 22^{\prime} 34.7^{\prime \prime} \mathrm{S} \\
60^{\circ} 19^{\prime} 207^{\prime \prime} \mathrm{W}\end{array}$ \\
\hline (2) Caiman latirostris & & São Paulo (BR) & $22^{\circ} 33^{\prime} 53.1^{\prime \prime} \mathrm{S}$ \\
\hline (Broad-snouted caiman) & $49,60^{7}$ & (Cerrado) & $48^{\circ} 00^{\prime} 35.2^{\prime \prime} \mathrm{W}$ \\
\hline (3) Caiman yacare & & Mato Grosso (BR) & $16^{\circ} 19^{\prime} 32.0^{\prime \prime} \mathrm{S}$ \\
\hline (Yacare caiman) & $2 \%, 80^{1}$ & (Pantanal) & $57^{\circ} 46^{\prime} 35.7^{\prime \prime} \mathrm{W}$ \\
\hline (4) Melanosuchus niger & $20.20^{\circ}$ & Amazonas (BR) & $3^{\circ} 25^{\prime} 50.4^{\prime \prime} \mathrm{S}$ \\
\hline (Black caiman) & & (Amazon Basin) & $66^{\circ} 02^{\prime} 35.0^{\prime \prime} \mathrm{W}$ \\
\hline (5) Paleosuchus palpebrosus & & Pará (BR) & $1^{\circ} 18^{\prime} 19.7^{\prime \prime} \mathrm{S}$ \\
\hline (Cuvier's dwarf caiman) & $3+, 30$ & (Amazon Basin) & $48^{\circ} 19^{\prime} 05.0^{\prime \prime} \mathrm{W}$ \\
\hline (6) Paleosuchus trigonatus & & Amazonas (BR) & $3^{\circ} 06^{\prime} 52.0^{\prime \prime} \mathrm{S}$ \\
\hline (Schneider's smooth-fronted caiman) & $3 q, 4 c$ & (Amazon Basin) & $60^{\circ} 01^{\prime} 58.0^{\prime \prime} \mathrm{W}$ \\
\hline $\begin{array}{c}\text { Alligator mississippiensis } \\
\text { (American alligator) }\end{array}$ & $2 q, 20^{7}$ & \multicolumn{2}{|c|}{$\begin{array}{c}\text { Canberra University collection } \\
\text { (Australia) }\end{array}$} \\
\hline $\begin{array}{l}\text { Alligator sinensis } \\
\text { (Chinese alligator) }\end{array}$ & $\begin{array}{l}4 \text { 우 } 10^{7}, 1 \\
\text { unsexed }\end{array}$ & \multicolumn{2}{|c|}{ Private collections (Germany) } \\
\hline
\end{tabular}

Chromosomal preparations were obtained by means of in vitro blood cultures $[57,58]$. Constitutive heterochromatin was identified by the C-banding method according to [59], CG- and AT-rich chromosomal regions were highlighted using Chromomycin $\mathrm{A}_{3}$ (CMA3) and 6-diamidino-2-phenylindole (DAPI), respectively [60].

\subsection{FISH with $r D N A$ and Repetitive Motifs}

We isolated 18S rDNA and (TTAGGG)n probes from the genome of $C$. latirostris according to [61] and [62], respectively, and directly labeled with Atto550-dUTP using the Nick-Translation mix kit (Jena Bioscience, Jena, Germany), following manufacturer's instructions. The repetitive motif (CGG) 10 was directly labeled with $\mathrm{Cy} 3$ during the commercial synthesis, as described by [63]. FISH followed the protocol described by [64], with minor modifications according to [41]. Chromosomes were counterstained with DAPI $(1.2 \mu \mathrm{g} / \mathrm{mL})$, and the slides were mounted in an antifade solution (Vector, Burlingame, CA, USA).

\subsection{Microdissection and Whole Chromosome Painting}

We selected chromosome No. 1 of A. mississippiensis for experiments of cross-species painting (sometimes also referred as Zoo-FISH), as it could be unambiguously identified as the largest chromosome of each metaphase. Twelve copies of this chromosome were isolated by glass-needle based microdissection and amplified using the procedure described in [65]. The probe was referred to as AMI-1, and it was labeled with Spectrum GreendUTP (Vysis, Downers Grove, IL, USA) in a secondary Degenerate Oligonucleotide-Primed Polymerase Chain Reaction (DOP PCR) using $1 \mu \mathrm{L}$ of the primarily amplified product as template DNA [65]. Zoo-FISH with the AMI-1 probe was applied on chromosomal preparations from all Alligatoridae species as described in [64]. 


\subsection{Comparative Genomic Hybridization}

We focused on interspecific genomic comparisons by CGH. The female-derived total genomic DNA (gDNA) of one representative of each genus (namely: C. latirostris, P. palpebrosus, $M$. niger, and A. sinensis) was compared with the female-derived gDNA of $C$. yacare. For that, separate CGH experiments were performed against metaphase chromosomes of C. yacare. The gDNAs were extracted from blood using the standard phenol-chloroformisoamyl alcohol method [66]. The gDNA of C. yacare was labeled with Atto550-dUTP by means of nick translation (Jena Bioscience, Jena, Germany), while the gDNAs of the other species were labeled with Atto488-dUTP also by nick translation (Jena Bioscience, Jena, Germany).

In all experiments, repetitive DNA sequences were blocked by unlabeled C0t-1 DNA (i.e., fraction of genomic DNA enriched for highly and moderately repetitive sequences), prepared according to [67]. The final probe cocktail for each slide was composed of $500 \mathrm{ng}$ of gDNA of C. yacare + $500 \mathrm{ng}$ of gDNA corresponding to one of the comparative species + $6 \mu \mathrm{g}$ of female-derived C0t-1 DNA of each species. The probe was ethanol-precipitated, and the dry pellets were resuspended in hybridization buffer containing 50\% formamide, $2 \times$ saline-sodium citrate buffer, $10 \%$ sodium dodecyl sulphate, $10 \%$ dextran sulfate and Denhardt's buffer, $\mathrm{pH}$ 7.0. The chosen ratio of probe vs. C0t-1 DNA amount was based on the previous experiments performed in reptiles [41]. The CGH experiments followed the methodology described in [68].

\subsection{Microscopic Analyses and Image Processing}

At least 10 metaphase spreads per individual were analyzed to confirm the $2 \mathrm{n}$ chromosome number, karyotype structure, and FISH results. Images were captured using an Olympus BX50 microscope (Olympus Corporation, Ishikawa, Japan) with a CoolSNAP CCD camera (Teledyne Photometrics, Tucson, AZ, USA), and the images were processed using Image Pro Plus 4.1 software (Media Cybernetics, Silver Spring, MD, USA). The chromosomes were classified as metacentric $(\mathrm{m})$, submetacentric $(\mathrm{sm})$, and acrocentric (a) according to [69].

\section{Results}

\subsection{Karyotypes, C-Banding, and Chromomycin $A_{3}$-Staining}

The $2 \mathrm{n}$ for all Caimaninae species equaled 42 for both sexes. Their karyotypes were composed of $24 \mathrm{a}+18 \mathrm{~m} / \mathrm{sm}$ chromosomes in C. crocodilus and C. latirostris; $28 \mathrm{a}+14 \mathrm{~m} / \mathrm{sm}$ chromosomes in C. yacare, P. palpebrosus, and P. trigonatus, and $32 \mathrm{a}+10 \mathrm{~m} / \mathrm{sm}$ chromosomes in M. niger. North American A. mississippiensis and Chinese A. sinensis had $2 \mathrm{n}=32$ and their karyotypes were invariably formed by $4 \mathrm{a}+28 \mathrm{~m} / \mathrm{sm}$ chromosomes. No intraindividual chromosomal variability was observed, neither that between males nor females, indicating the absence of heteromorphic sex chromosomes.

Therefore, these data extended and consolidated previous information for these species [43-46,51,54,70-74]. C-positive heterochromatic bands were detected at the centromeric regions of almost all chromosomes, with more prominent bands in the rDNAbearing chromosome pair(s) (Figures 2 and 3). CMA3+ bands occurred in almost all centromeric regions, with very bright signals observed in the smallest chromosomes (Figure 4). 




Figure 2. Female karyotypes of Caiman crocodilus $(\mathbf{a}-\mathbf{c})$, C. latirostris $(\mathbf{d}-\mathbf{f})$, C. yacare $(\mathbf{g}-\mathbf{i})$, Melanosuchus niger (j-1), Paleosuchus palpebrosus (m-o) and P. trigonatus ( $\mathbf{p}-\mathbf{r})$ arranged after inverted-DAPI staining $(\mathbf{a}, \mathbf{d}, \mathbf{g}, \mathbf{j}, \mathbf{m}, \mathbf{p})$, C-banding $(\mathbf{b}, \mathbf{e}, \mathbf{h}, \mathbf{k}, \mathbf{n}, \mathbf{q})$ and FISH with $18 \mathrm{~S}$ rDNA (red) probe $(\mathbf{c}, \mathbf{f}, \mathbf{i}, \mathbf{l}, \mathbf{o}, \mathbf{r})$. Bar $=20 \mu \mathrm{m}$.


Figure 3. Female karyotypes of Alligator mississippiensis (a-c) and A. sinensis $(\mathbf{d}-\mathbf{f})$ arranged after inverted-DAPI staining (a,d), C-banding (b,e), and FISH analysis with $18 \mathrm{~S}$ rDNA (red) probe $(\mathbf{c}, \mathbf{f})$. Bar $=20 \mu \mathrm{m}$. 


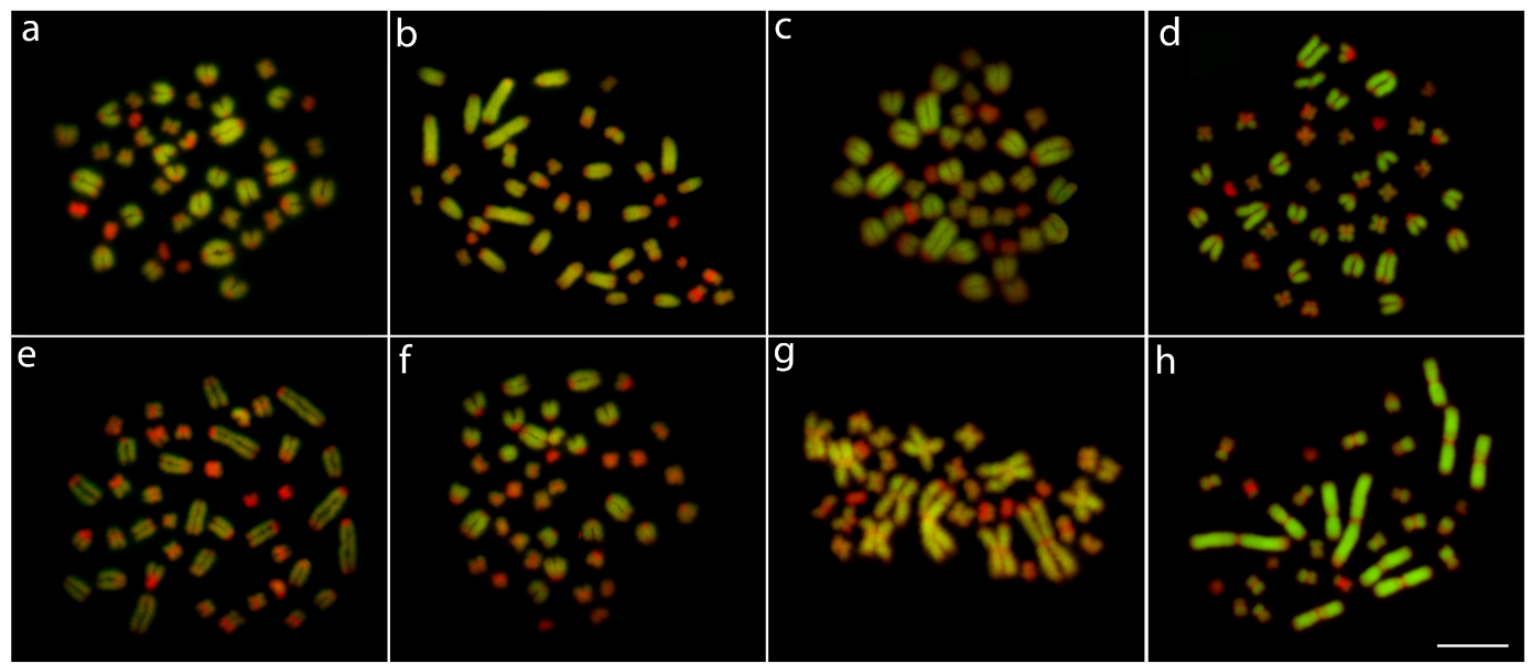

Figure 4. Metaphase chromosomes from females of Caiman crocodilus (a), C. latirostris (b), C. yacare (c), Melanosuchus niger (d), Paleosuchus palpebrosus (e), P. trigonatus (f), Alligator mississippiensis (g), and A. sinensis (h) after CMA3/DAPI banding (GC- and AT-rich regions pseudocolored in red and green, respectively). Bar $=20 \mu \mathrm{m}$.

\subsection{Fluorescence In Situ Hybridization (FISH) Mapping of Repetitive DNAs}

Two distinct patterns of distribution of $18 \mathrm{~S}$ rDNA sites were observed. In all three Caiman spp., M. niger, and both Alligator spp., these sites were located in the centromeric region of a single metacentric pair No. 18. However, in karyotypes of both Paleosuchus spp., six chromosomes displayed 18S rDNA sites (Figures 2 and 3). (CGG) 10 showed positive hybridization signals in all species, ranging from four to eight chromosomes containing these motifs.

In addition to signals on four small chromosomes (only two in Melanosuchus), all the studied species shared a signal in the terminal position of the largest chromosome pair, except for both Paleosuchus spp. where the signal with these particular sites was lacking, but with signals present on four other small chromosomes instead (Figure 5). FISH with the telomeric (TTAGGG)n probe performed in four species (C. latirostris, P. palpebrosus, A. mississippiensis, and $A$. sinensis) hybridized only to the telomeric regions of all chromosomes, without interstitial telomeric sites (ITSs) (Figure S1).
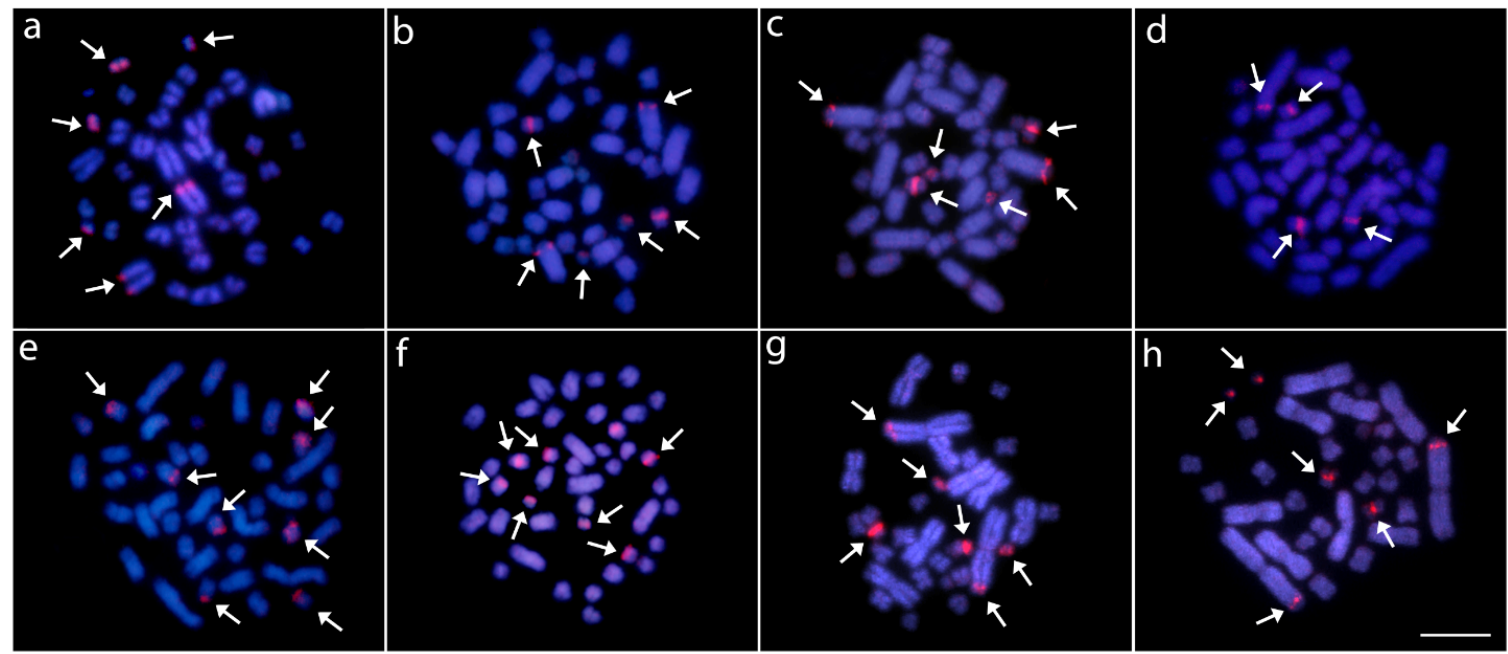

Figure 5. Metaphase chromosomes from females Caiman crocodilus (a), C. latirostris (b), C. yacare (c), Melanosuchus niger (d), Paleosuchus palpebrosus (e), P. trigonatus (f), Alligator mississippiensis (g), and A. sinensis (h) hybridized with (CGG) microsatellite probe (red). Chromosomes were counterstained with DAPI (blue). Arrows indicate the CGG+ signals. Bar $=20 \mu \mathrm{m}$. 


\subsection{WCP of AMI-1 Probe}

The AMI-1 probe, when applied against metaphase chromosomes of $A$. mississippiensis and $A$. sinensis, completely painted the largest metacentric chromosome pair. Otherwise, its hybridization to Caimaninae species consistently painted two acrocentric chromosomal pairs (Figure 6).
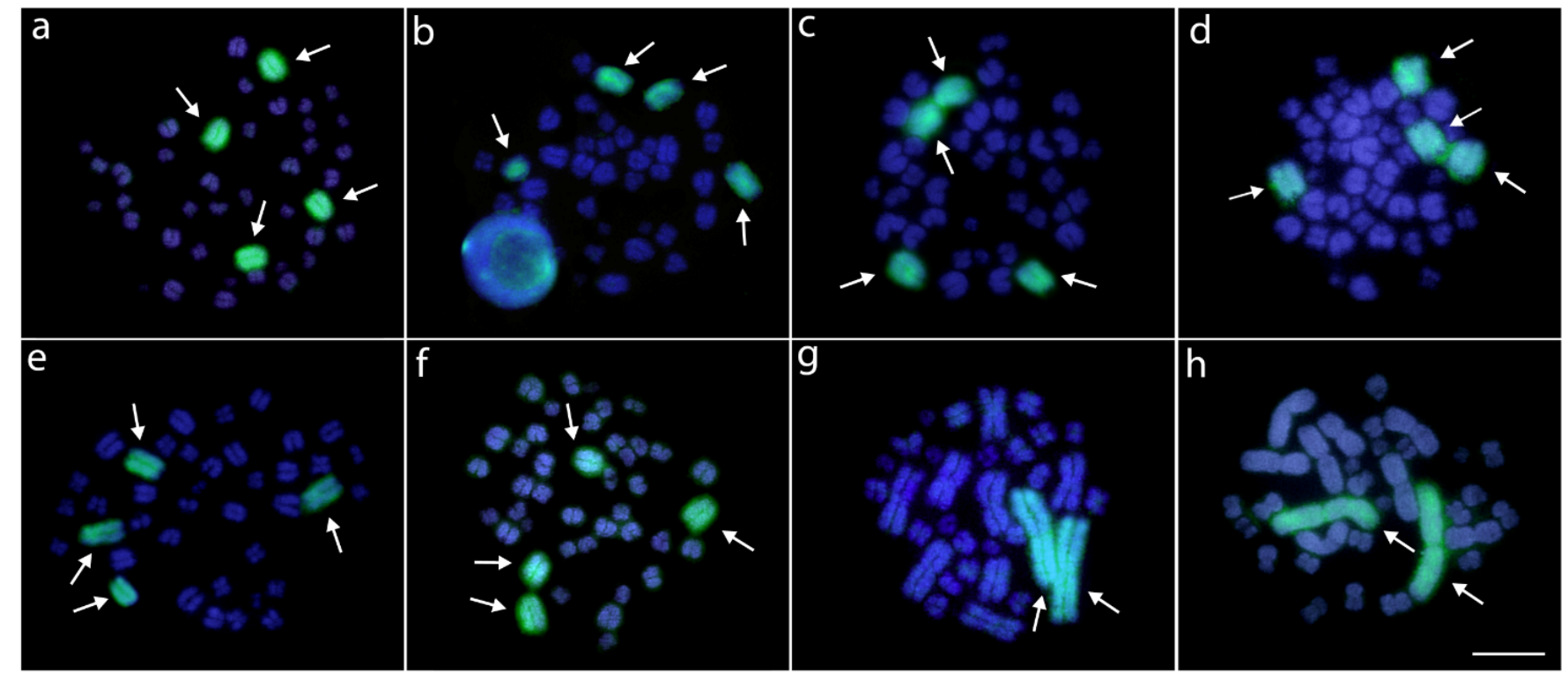

Figure 6. Zoo-FISH experiments with the AMI-1 painting probe (green) applied against female metaphase plates of Caiman crocodilus (a), C. latirostris (b), C. yacare (c), Melanosuchus niger (d), Paleosuchus palpebrosus (e), P. trigonatus (f), Alligator mississippiensis (g), and A. sinensis (h). Chromosomes were counterstained with DAPI (blue). Arrows indicate the chromosomes painted with AMI-1 probe. Bar $=20 \mu \mathrm{m}$.

\subsection{Comparative Genomic Hybridization (CGH)}

The gDNA of $C$. yacare hybridized against its own chromosome complement highlighted abundant heterochromatic blocks in the centromeric regions of several chromosomes. The CGH experiments using gDNA probes from C. latirostris and M. niger on C. yacare chromosomes demonstrated several overlapping signals in the centromeric regions, indicating that the centromeres of these species are enriched in similar repetitive sequences, although M. niger in smaller amounts and/or in different repeats. However, P. palpebrosus and A. sinensis shared a little of repetitive content with $C$. yacare, restricted almost exclusively to the $18 \mathrm{~S}$ rDNA-bearing pair(s), indicating their high degree of centromeric sequence differentiation (Figure 7). 


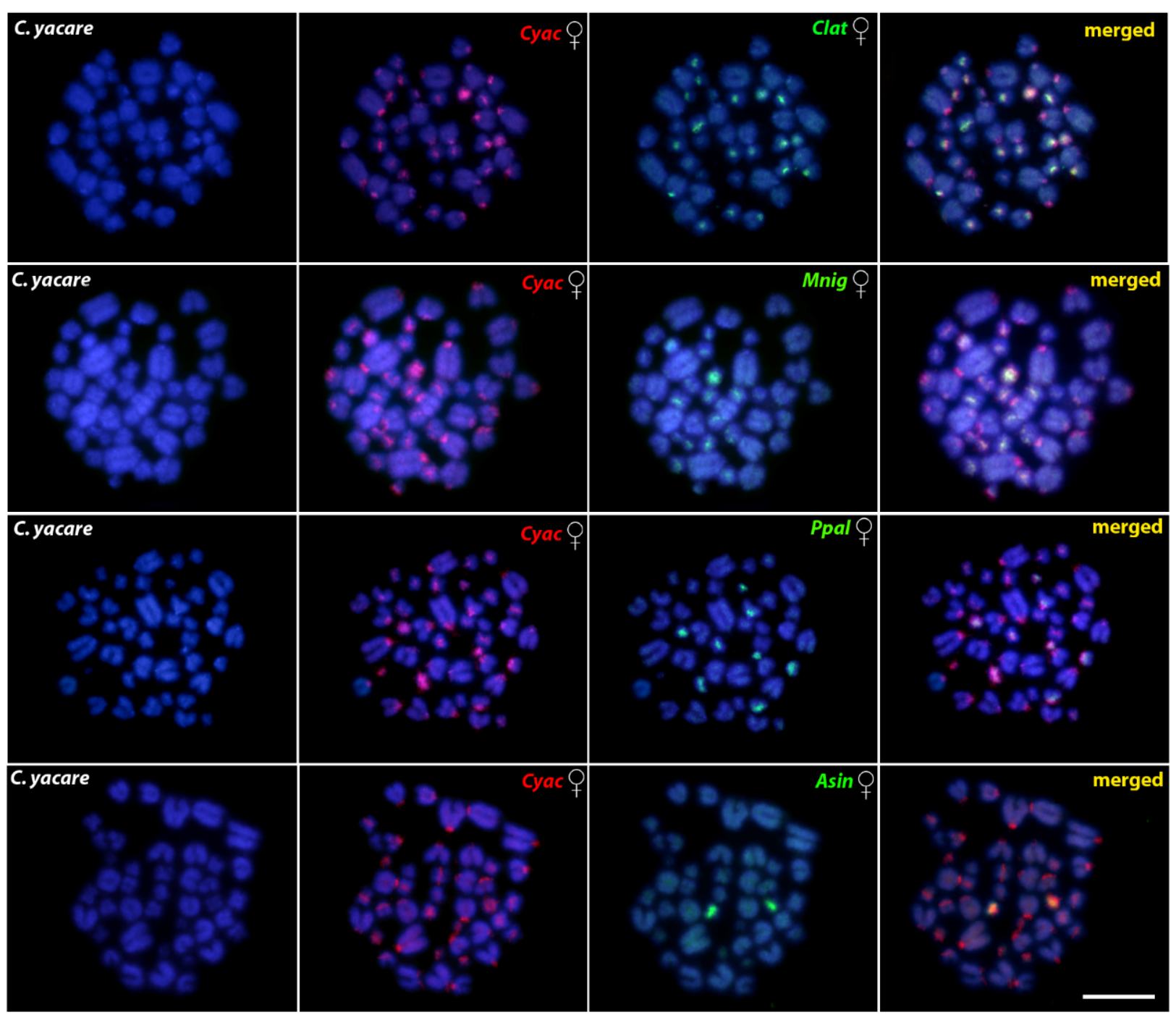

Figure 7. Mitotic chromosome spreads of Caiman yacare females after CGH-inter-specific hybridizations. First column: DAPI images (blue). Second column: hybridization pattern of the female-derived probe (red) of C. yacare. Third column: hybridization pattern of the female-derived probe (green) of each analyzed species. Fourth column: merged images of both genomic probes and DAPI staining. The common genomic regions are depicted in yellow. Clat $=$ C. latirostris, Cyac $=C$. yacare, $\mathrm{Mnig}=$ M. niger, $\mathrm{Ppal}=$ P. palpebrosus, and Asin $=$ A. sinensis. $\mathrm{Bar}=10 \mu \mathrm{m}$.

\section{Discussion}

The evolutionary history of non-avian reptiles (turtles, crocodilians, and squamates) led to an accentuated asymmetric species-richness among its groups - from the 11.341 living species, only approximately $26(0.23 \%)$ are crocodilians [20]. As the crocodylomorph group has inhabited the Earth for more than $\sim 100$ million years (Myr) and represents adaptations to different food and habitat niches, the intriguing open question is, why are there so few extant living crocodilian species? [4]. Alfaro et al. [75] found that they are diversifying 1000-times slower than expected. This goes also together with a low disparity rate, being about 10,000 times smaller than that of other groups having the same evolutionary time scale, such as birds and lepidosaurs [76,77].

This low rate of diversification over time may somehow be related to the crocodilians karyotype evolution [1,44]. While birds $(2 n=40-142)$, turtles $(2 n=28-68)$, and squamate reptiles $(2 n=16-62)$ have higher levels of variability in diploid chromosome number and karyotype morphology, crocodilians present much less variation in their karyotypes $[30,31,52,53,78,79]$. In fact, the cytogenetic investigation of 23 out of 26 crocodilian 
species reveals general karyotypic patterns as they present a lower $2 n=30-42$ and the predominance of a few large chromosomes, together with the absence of dot-shaped microchromosomes in their karyotypes [17]. The predicted ancestral karyotype for archosaurs + turtles shows at least eight pairs of macrochromosomes and many indistinguishable microchromosomes. In this way, the crocodilian lineage strikingly diverges from that ancestral pattern, since all microchromosomes disappeared by fusion events among them [49].

While $2 \mathrm{n}$ ranges from 30 to 34 in representatives of Crocodylidae and Gavialidae (except for the African dwarf crocodile Osteolaemus tetraspis, with $2 \mathrm{n}=38$ ), two major pathways can be recognized in the chromosomal differentiation inside Alligatoridae: (i) conservation of the low diploid number $(2 \mathrm{n}=32)$ and karyotypes composed of mostly bi-armed chromosomes in A. mississippiensis and A. sinensis ([44], this study); and (ii) a higher chromosome number $2 \mathrm{n}=42$ in Caiman, Melanosuchus, and Paleosuchus spp., with karyotypes dominated by acrocentric elements ([44,51], this study).

This suggests that extensive chromosomal rearrangements must have occurred in the karyotype evolution at the split of Alligatorinae and Caimaninae. Since a lower $2 \mathrm{n}$ can be recognized as the ancestral condition for the Crocodylia order [17], it is likely that karyotype diversification in the common ancestor of all Caimaninae species was accompanied by a series of fission events after the split of Alligator ( $70 \mathrm{Myr}$ [ [80], thus, increasing the $2 \mathrm{n}$ value. Our Zoo-FISH results support this scenario by highlighting the homeology of the largest metacentric chromosomal pair present in both Alligator species with four smaller acrocentric chromosomes in all three Caimaninae genera (Figure 6).

The alternative hypothesis considering $2 n=42$ as the plesiomorphic state might be valid under this scenario with caimans being a sister lineage to all other crocodilians. However, regarding current phylogeny, the Alligatorinae + Caimaninae is sister to Crocodylidae + Gavialidae, the alternative hypothesis is supported neither by $2 n=30-32$ widely distributed in all other Crocodylia lineages, nor by our telomeric FISH results. Interstitial telomeric sequences (ITS) might reflect the remnants of telomeres in neo-chromosomes originated by the chromosome fusion of two ancestral chromosomes [81]. However, in alligators, only the standard terminal topology of telomeres is found in all chromosomes, with no ITS indicating probable fusion points in the large metacentrics (Figure S1). Therefore, although crocodilians do not exhibit a high karyotype divergence among their living species, the various chromosomal rearrangements, especially those present in the caimans, might have played a role in the species radiation. In this context, it cannot be ruled out that the increase in $2 \mathrm{n}$ may have favored a higher rate of recombination, due to an increase in independent chromosomal segregation during meiosis, thus, likely bringing some advantage to the colonizing specimens of the new South American environment.

In most reptiles and birds, rDNA clusters are frequently located in a single chromosome pair $[53,82,83]$, with few exceptions showing an amplified number of rDNA sites in snakes [84,85], lizards [86], turtles [87], and birds (reviewed in [53]). Here, this same general pattern is also followed by all Alligatoridae species, except both examined Paleosuchus species, in which three chromosome pairs bear these sequences (Figure 2). In fact, single rDNA sites are usually found in old lineages, as also observed in ancient fish groups, e.g., ancient non-teleost actinopterygian fishes [83].

Chromosomes displaying sequences shorter than $30 \mathrm{Mb}$ - the microchromosomesare widely documented in almost all vertebrate groups [88]. Specifically, the extant sauropsids (some reptiles and birds) generally also present these major components in their karyotypes $[89,90]$. In turtles and birds, microchromosomes exhibit a higher gene density and GC-content [91-95]. Similarly, microchromosomes of the squamate reptiles also display GC-rich content in comparison with macrochromosomes, although their CMA3+ signals are never as bright as in birds (e.g., [58]), a difference in the chromosome/genome composition that is also confirmed by genomic approaches [88].

Our results demonstrated that all Alligatoridae species also possess a high accumulation of GC-positive blocks on small chromosomes with strong and sharp signals co-localized with the $18 \mathrm{~S}$ rDNA clusters. This pattern can be ascribed as unique, showing a 
similar and preserved G-banding pattern in the whole order [45]. The poorer GC-positive pattern in the largest chromosomes indicates sequence-specific regions, a characteristic that influences the reduction of the chromosomal recombination rate [96].

Turtles and crocodiles have larger genomes, with a more variable DNA content when compared to other reptiles, mainly due to the tendency to accumulate and preserve repetitive DNA [30,73]. They also have few Simple Short Repeats (SSR) when compared to other lizard species [97]. In fact, microsatellites or SSRs are one of the broadest and most representative DNA class in several vertebrate species [98-100] and are known to display a dynamic role in the genomic functioning [101]. Due to their high rates of mutation and fast evolution, usually modulated by an association with mobile elements [102-105], the genome landscapes may vary drastically among related groups.

Non-avian reptiles, for instance, stand out in such a scenario [99,106,107]. Interestingly, crocodilians seem to be the poorest group concerning SSR content among avian and nonavian reptiles $[7,99]$, being that the density and content of SSR repeats are relatively similar among species, with slow rates of mutation and evolution when compared to other lineages. Alligators and caimans constitute a unique group with any SSR mapping data up to now, and (CGG) $)_{n}$ showed some accumulation but in only two chromosome pairs in M. niger, three pairs in Caiman and Alligator species, and four pairs in Paleosuchus species.

Although conservative, the repetitive DNA fraction shows divergences among Caimaninae species, as demonstrated by our CGH experiments where both Paleosuchus species stand out as the most divergent ones (Figure 7). Following the phylogenetic hypothesis, the cytogenetic similarity of centromeric repeats between Caiman and M. niger (diverged at $\sim 12 \mathrm{Myr}$ ) was higher compared to Paleosuchus, which are phylogenetically distant and diverged from the genera Caiman + Melanosuchus at 22 Myr [12]. The extensively shared cytogenetic features of Caiman and Melanosuchus are also supported by the CGH experiments, with little differences in the overall hybridization patterns demonstrating a high degree of sequence homology.

Although the evolutionary divergence time among the Caimaninae may not have been long enough for the fixation of karyotype differences regarding the $2 \mathrm{n}$ and karyotype composition, it allowed the changes in the patterns of the repetitive DNA fraction due to the different evolutionary dynamics. The CGH experiments between Caimaninae and Alligatorinae suggested an advanced stage of sequence divergence, except for the bright signals, highly likely corresponding to NOR sites (as might be compared with previous rDNA FISH analysis). Such a similar scenario was already previously reported for distantly related or substantially diverged genomes [108-110].

The progressive temporal reduction of the chromosome homology in Caimaninae appears to have occurred slowly and suggests a tendency of an internal reorganization in chromosomes operating to gradually reduce the degree of collinearity and conserved synteny, as observed in several animal groups [111]. Karyotype stasis, characterized by the absence of conspicuous modifications throughout the evolutionary history, has already been discovered in many biological groups, such as plants [112-114], amphibians [115,116], birds [117], and fishes [118,119]. Among fishes, for example, the Gondwanan notopterids (Teleostei, Osteoglossiformes), whose species diverged by more than $100 \mathrm{Myr}$, display conserved karyotypes along such evolutionary time scales, with only slight disturbances of collinearity $[110,120]$.

However, the maintenance of such conservative traits for millions of years is not always well understood and suggests some possible causes, such as stabilizing selection [121], a punctuated model of evolution [122], or orthoselective processes [123,124]. In crocodilians, the ancient periods of evolutionary divergence among its lineages do not support the hypothesis that karyotype stasis is a byproduct of recent processes of speciation. As karyotype and chromosome diversifications may accompany speciation [125-127], the low crocodilian species diversity might be directly linked with their karyotype features, which must have been influenced by the climactic fluctuations that occurred during the Cenozoic period [4]. 


\section{Conclusions}

This study is the first to offer reliable chromosomal data for all taxonomically recognized Alligatoridae species based on both conventional and molecular cytogenetic data and to provide a first view on the evolutionary history and chromosomal evolution of alligators and caimans. We observed a stable dichotomy among the genera Alligator $(2 \mathrm{n}=32)$ and Caiman, Melanosuchus, and Paleosuchus $(2 n=42)$, where $2 n=32$ represents the likely ancestral state, which is also supported by other chromosomal data. Therefore, karyotype diversification in Caimaninae was followed by a series of Robertsonian rearrangements in which centric fissions played a key role. Additional investigations into the relationships between North American and Chinese alligators with caimans in South America may provide further information on the role of biogeographic factors in karyotype differentiations in Crocodylia.

Supplementary Materials: The following are available online at https:/ /www.mdpi.com/article/10 .3390 /cells10061397/s1, Figure S1: Metaphase plates of females from C. latirostris (a), P. palpebrosus (b), A. mississippiensis (c), and A. sinensis (d) with telomeric (TTAGGG)n probe (red). Bar $=5 \mu \mathrm{m}$.

Author Contributions: Formal analysis, V.C.S.O., M.A., P.F.V., and M.d.B.C.; Funding acquisition, T.L. and M.d.B.C.; Investigation, V.C.S.O., M.A., T.E., P.R., T.L., T.H., and A.M.; Methodology, V.C.S.O., M.A., P.F.V., A.A.-R., T.H., S.S., A.M., and M.d.B.C.; Project administration, M.d.B.C.; Supervision, T.L. and M.d.B.C.; Validation, V.C.S.O., M.A., P.F.V., T.E., L.A.C.B., P.R., T.L., E.F., and S.S.; Visualization, T.E., L.A.C.B., P.R., A.A.-R., E.F., T.H., S.S., A.M., and M.d.B.C.; Writing—original draft, V.C.S.O.; Writing-review \& editing, M.A., P.F.V., T.E., L.A.C.B., P.R., T.L., A.A.-R., E.F., T.H., S.S., A.M., and M.d.B.C. All authors have read and agreed to the published version of the manuscript.

Funding: M.A. was supported by the Charles University Research Centre programme 204069 and by Czech Science Foundation project No. 20-27236J. M.d.B.C. was supported by the Conselho Nacional de Desenvolvimento Científico e Tecnológico (CNPq) (302449/2018-3) and Fundação de Amparo à Pesquisa do Estado de São Paulo (FAPESP) (2018/22033-1). This study was financed in part by the Coordenação de Aperfeiçoamento de Pessoal de Nível Superior, Brasil (CAPES), Finance Code 001.

Institutional Review Board Statement: The study was conducted according to the guidelines of the Ethics Committee on Animal Experimentation of the Universidade Federal de São Carlos (Process number CEUA 4617090919). Collections were done under the authorization of the Chico Mendes Institute for Biodiversity Conservation (ICMBIO), System of Authorization and Information about Biodiversity (SISBIO-License No. 71857-7), and National System of Genetic Resource Management and Associated Traditional Knowledge (SISGEN-ABFF266). Blood samples from Alligator sinensis came from animals legally kept in Europe (CITES certificate number EU 0228-1057/14, ES-CC00041/07C, ES-CC-00036/07C, 50721-18, DE-DA190814-5, DE-DA190814-6).

Data Availability Statement: Not applicable.

Acknowledgments: We would like to thank to Crocodile working group of the German Society for Herpetology and Terrarium Science association (DGHT AG Krokodile) for providing contact to keepers of alligators, Šárka Pelikánová (IAPG CAS) for the lab support. We are grateful to the São Carlos Environmental Police (Policia Ambiental São Carlos), Alysson Luciano Vieira, and Hugmar Pains da Silva for all logistical and technical support. We are also grateful to Milena and Breno Almeida from the Amazonian Center for Herpetology (Centro Amazônico de Herpetologia) for all the valuable support provided with sampling and to Francisco de Menezes Cavalcante Sassi of the Federal University of São Carlos (UFSCar) for assistance in the elaboration of the maps that are present in Figure 1.

Conflicts of Interest: The authors declare no conflict of interest.

\section{References}

1. Grigg, G.; Seebacher, F.; Franklin, C.E. (Eds.) Crocodilian Biology and Evolution, 1st ed.; Surrey Beatty: Chipping Norton, Australia, 2001; p. 446.

2. Brochu, C.A. Phylogenetic approaches toward crocodylian history. Annu. Rev. Earth and Planet. Sci. 2003, 31, 357-397. [CrossRef]

3. Bronzati, M.; Montefeltro, F.C.; Langer, M.C. Diversification events and the effects of mass extinction on Crocodyliformes evolutionary history. R. Soc. Open Sci. 2015, 2, 140385. [CrossRef] 
4. Stubbs, T.L.; Pierce, S.E.; Elsler, A.; Anderson, P.S.L.; Rayfield, E.J.; Benton, M.J. Ecological opportunity and the rise and fall of crocodylomorph evolutionary innovation. Proc. R. Soc. B 2021, 288, 20210069. [CrossRef]

5. Janke, A.; Arnason, U. The complete mitochondrial genome of Alligator mississippiensis and the separation between recent Archosauria (birds and crocodiles). Mol. Biol. Evol. 1997, 14, 1266-1272. [CrossRef]

6. Iwabe, N.; Hara, Y.; Kumazawa, Y.; Shibamoto, K.; Saito, Y.; Miyata, T.; Katoh, K. Sister group relationship of turtles to the bird-crocodilian clade revealed by nuclear DNA-coded proteins. Mol. Biol. Evol. 2005, 22, 810-813. [CrossRef]

7. Green, R.E.; Braun, E.L.; Armstrong, J.; Earl, D.; Nguyen, N.; Hickey, G.; Vandewege, M.W.; St. John, J.A.; Capella-Gutiérrez, S.; Castoe, T.A. Three crocodilian genomes reveal ancestral patterns of evolution among archosaurs. Science 2014, $346,1254449$. [CrossRef]

8. Pan, T.; Miao, J.-S.; Zhang, H.-B.; Yan, P.; Lee, P.-S.; Jiang, X.-Y.; Ouyang, J.-H.; Deng, Y.-P.; Zhang, B.-W.; Wu, X.-B. Near-complete phylogeny of extant Crocodylia (Reptilia) using mitogenome-based data. Zool. J. Linn. Soc. 2021, 191, 1075-1089. [CrossRef]

9. Espinosa, E.; Godshalk, R.; Hall, P.; Thorbjarnarson, J.; Tucker, A.; Verdade, L. Species Accounts. In Status Survey and Conservation Action Plan: Revised Action Plan for Crocodiles, 2nd ed.; Ross, P., Ed.; IUCN/SSC Crocodile Specialist Group: Gland, Switzerland; Cambridge, UK, 1998; Volume 1, pp. 3-73.

10. Rueda-Almonacid, J.V.; Carr, J.L.; Mittermeier, R.A.; Rodríguez-Mahecha, J.V.; Mast, R.B.; Vogt, R.C.; Rhodin, A.G.J.; OssaVelásquez, J.O.; Rueda, J.N.; Mittermeier, C.G. Orden Crocodylia. In Conservación Internacional. Serie de Guías Tropicales de Campo $N^{\circ}$ 6. Las Tortugas y lós Crocodilianos de los Países Andinos del Trópico, 1st ed.; Mittermeier, R.A., Rylands, A., Eds.; Editorial Panamericana, Formas e Impresos: Bogotá, Colombia, 2007; Volume 1, pp. 387-432.

11. Meredith, R.W.; Hekkala, E.R.; Amato, G.; Gatesy, J. A phylogenetic hypothesis for Crocodylus (Crocodylia) based on mitochondrial DNA: Evidence for a trans-Atlantic voyage from Africa to the New World. Mol. Phylogenet. Evol. 2011, 60, 183-191. [CrossRef]

12. Oaks, J.R. A time-calibrated species tree of Crocodylia reveals a recent radiation of the true crocodiles. Evolution 2011, 65, 3285-3297. [CrossRef]

13. McAliley, L.R.; Willis, R.E.; Ray, D.A.; White, P.S.; Brochu, C.A.; Densmore, L.D. Are crocodiles really monophyletic?-Evidence for subdivisions from sequence and morphological data. Mol. Phylogenet. Evol. 2006, 39, 16-32. [CrossRef]

14. Martin, S. Global diversity of crocodiles (Crocodilia, Reptilia) in freshwater. Hydrobiologia 2008, 595, 587-591. [CrossRef]

15. Hekkala, E.; Shirley, M.H.; Amato, G.; Austin, J.D.; Charter, S.; Thorbjarnarson, J.; Vliet, K.A.; Houck, M.L.; Desalle, R.; Blum, M.J. An ancient icon reveals new mysteries: Mummy DNA resurrects a cryptic species within the Nile crocodile. Mol. Ecol. 2011, 20, 4199-4215. [CrossRef]

16. Shirley, M.H.; Vliet, K.A.; Carr, A.N.; Austin, J.D. Rigorous approaches to species delimitation have significant implications for African crocodilian systematics and conservation. Proc. R. Soc. B 2014, 281, 20132483. [CrossRef]

17. Srikulnath, K.; Thapana, W.; Muangmai, N. Role of chromosome changes in Crocodylus evolution and diversity. Genom. Inform. 2015, 13, 102-111. [CrossRef]

18. Barreiros, J.P. Crocodylia: Uma Longa História de Sucesso Evolutivo, 1st ed.; Atlântida Revista de Cultura: Açores, Portugal, 2016; pp. 1-12.

19. Muniz, F.L.; Ximenes, A.M.; Bittencourt, P.S.; Hernández-Rangel, S.M.; Campos, Z.; Hrbek, T.; Farias, I.P. Detecting population structure of Paleosuchus trigonatus (Alligatoridae: Caimaninae) through microsatellites markers developed by next generation sequencing. Mol. Biol. Rep. 2019, 46, 1-12. [CrossRef]

20. Uetz, P.; Freed, P.; Aguilar, R.; Hošek, J. (Eds.) The Reptile Database. Available online: http:/ / www.reptile-database.org (accessed on 31 August 2020).

21. Nicolai, M.P.J.; Matzke, N.J. Trait-based range expansion aided in the global radiation of Crocodylidae. Glob. Ecol. Biogeogr. 2019, 28, 1244-1258. [CrossRef]

22. Shirley, M.H.; Carr, A.N.; Nestler, J.H.; Vliet, K.A.; Brochu, C.A. Systematic revision of the living African slender-snouted crocodiles (Mecistops Gray, 1844). Zootaxa 2018, 4504, 151-193. [CrossRef]

23. Bezuijen, M.R.; Shwedick, B.; Simpson, B.K.; Staniewicz, A.; Stuebing, R. Tomistoma schlegelii. IUCN Red List Threat. Species 2014, 2014, E.T21981A2780499. [CrossRef]

24. Lee, M.S.Y.; Yates, A.M. Tip-dating and homoplasy: Reconciling the shallow molecular divergences of modern gharials with their long fossil record. Proc. R. Soc. B. 2018, 285, 20181071. [CrossRef]

25. Muniz, F.L.; Campos, Z.; Rangel, S.M.H.; Martínez, J.G.; Souza, B.C.; De Thoisy, B.; Botero-Arias, R.; Hrbek, T.; Farias, I.P. Delimitation of evolutionary units in Cuvier's dwarf caiman, Paleosuchus palpebrosus (Cuvier, 1807): Insights from conservation of a broadly distributes species. Conserv. Genet. 2018, 19, 599-610. [CrossRef]

26. Bittencourt, P.S.; Campos, Z.; Muniz, F.L.; Marioni, B.; Souza, B.C.; Da Silveira, R.; de Thoisy, B.; Hrbek, T.; Farias, I.P. Evidence of cryptic lineages within a small South American crocodilian: The Schneider's dwarf caiman Paleosuchus trigonatus (Alligatoridae: Caimaninae). PeerJ 2019, 7, e6580. [CrossRef]

27. Balaguera-Reina, S.A.; Velasco, A. Caiman crocodilus. IUCN Red List Threat. Species 2019, 2019, E.T46584A3009688. [CrossRef]

28. Jiang, H.; Wu, X. Alligator sinensis. IUCN Red List Threat. Species 2018, 2018. [CrossRef]

29. Thorbjarnarson, J.; Wang, X.; Ming, S.; He, L.; Ding, Y.; Wu, Y.; McMurry, S.T. Wild populations of the Chinese alligator approach extinction. Biol. Conserv. 2002, 103, 93-102. [CrossRef]

30. Olmo, E. Trends in the evolution of reptilian chromosomes. Integr. Comp. Biol. 2008, 48, 486-493. [CrossRef] [PubMed] 
31. Deakin, J.E.; Ezaz, T. Understanding the evolution of reptile chromosomes through applications of combined cytogenetics and genomics approaches. Cytogenet. Genome Res. 2019, 157, 7-20. [CrossRef]

32. Straková, B.; Rovatsos, M.; Kubička, L.; Kratochvíl, L. Evolution of sex determination in amniotes: Did stress and sequential hermaphroditism produce environmental determination? BioEssays 2020, 42, e2000050. [CrossRef]

33. Ezaz, T.; Quinn, A.E.; Miura, I.; Sarre, S.D.; Georges, A.; Graves, J.A.M. The dragon lizard Pogona vitticeps has ZZ/ZW micro-sex chromosomes. Chromosome Res. 2005, 13, 763-776. [CrossRef]

34. Ezaz, T.; Valenzuela, N.; Grützner, F.; Miura, I.; Georges, A.; Burke, R.L.; Graves, J.A.M. An XX/XY sex michrocromosome system in a freshwater turtle, Chelodina longicollis (Testudines: Chelidae) with genetic sex determination. Chromosome Res. 2006, 14, 139-150. [CrossRef]

35. Kawai, A.; Nishida-Umehara, C.; Ishijima, J.; Tsuda, Y.; Ota, H.; Matsuda, Y. Different origins of bird and reptile sex chromosomes inferred from comparative mapping of chicken Z-linked genes. Cytogenet. Genome Res. 2007, 117, 92-102. [CrossRef]

36. Martinez, P.A.; Ezaz, T.; Valenzuela, N.; Georges, A.; Graves, J.A.M. An XX/XY heteromorphic sex chromosome system in the Australian chelid turtle Emydura macquarii: A new piece in the puzzle of sex chromosome evolution in turtles. Chromosome Res. 2008, 16, 815-825. [CrossRef]

37. Badenhorst, D.; Stanyon, R.; Engstrom, T.; Valenzuela, N. A ZZ/ZW microchromosome system in the spiny softshell turtle, Apalone spinifera, reveals an intriguing sex chromosome conservation in Trionychidae. Chromosome Res. 2013, 21, 137-147. [CrossRef]

38. Koubová, M.; Pokorná, M.J.; Rovatsos, M.; Farkačová, K.; Altmanová, M.; Kratochvil, L. Sex determination in Madagascar geckos of the genus Paroedura (Squamata: Gekkonidae) are differentiated sex chromosomes indeed so evolutionary stable? Chromosome Res. 2014, 22, 441-452. [CrossRef] [PubMed]

39. Matsubara, K.; Gamble, T.; Matsuda, Y.; Zarkower, D.; Sarre, S.D.; Georges, A.; Graves, J.A.M.; Ezaz, T. Non-homologous sex chromosomes in two geckos (Gekkonidae: Gekkota) with female heterogamety. Cytogenet. Genome Res. 2014, 143, 251-258. [CrossRef]

40. Montiel, E.E.; Badenhorst, D.; Tamplin, J.; Burke, R.L.; Valenzuela, N. Discovery of the youngest sex chromosomes reveals first case of convergent co-option of ancestral autosomes in turtles. Chromosoma 2016, 126, 105-113. [CrossRef] [PubMed]

41. Viana, P.F.; Ezaz, T.; Cioffi, M.B.; Almeida, B.J.; Feldberg, E. Evolutionary Insights of the ZW Sex Chromosomes in Snakes: A New Chapter Added by the Amazonian Puffing Snakes of the Genus Spilotes. Genes 2019, 10, 288. [CrossRef] [PubMed]

42. Viana, P.F.; Ezaz, T.; Cioffi, M.B.; Liehr, T.; Al-Rikabi, A.; Goll, L.G.; Rocha, A.M.; Feldberg, E. Landscape of snake' sex chromosomes evolution spanning 85 MYR reveals ancestry of sequences despite distinct evolutionary trajectories. Sci. Rep. 2020, 10, 12499. [CrossRef] [PubMed]

43. Cohen, M.M.; Clark, H.F. The somatic chromosomes of five crocodilian species. Cytogenetics 1967, 6, 193-203. [CrossRef]

44. Cohen, M.M.; Gans, C. The chromosomes of the Order Crocodilia. Cytogenetics 1970, 9, 81-105. [CrossRef]

45. King, M.; Honeycutt, R.; Contreras, N. Chromosomal repatterning in crocodiles: C, G, and N-banding and the in situ hybridization of $18 \mathrm{~S}$ and 26S rRNA cistrons. Genetica 1986, 70, 191-201. [CrossRef]

46. Lui, J.F.; Valencia, E.F.T.; Boer, J.A. Karyotypic analysis and chromosome biometry of cell cultures of the yellow throated alligator (Caiman latirostris DAUDIN). Rev. Brasil. Genet. 1994, 17, 165-169.

47. Valleley, E.M.A.; Harrison, C.J.; Cook, Y.; Ferguson, M.W.J.; Sharpe, P.T. The karyotype of Alligator mississippiensis, and chromosomal mapping of the ZFY/X homologue, Zff. Chromosoma 1994, 103, 502-507. [CrossRef] [PubMed]

48. Kawagoshi, T.; Nishida, C.; Ota, H.; Kumazawa, Y.; Endo, H.; Matsuda, Y. Molecular structures of centromeric heterochromatin and karyotypic evolution in the Siamese crocodile (Crocodylus siamensis) (Crocodylidae, Crocodylia). Chromosome Res. 2008, 16, 1119-1132. [CrossRef]

49. Uno, Y.; Nishida, C.; Tarui, H.; Ishishita, S.; Takagi, C.; Nishimura, O.; Ishijima, J.; Ota, H.; Kosaka, A.; Matsubara, K.; et al. Inference of the protokaryotypes of amniotes and tetrapods and the evolutionary processes of microchromosomes from comparative gene mapping. PLoS ONE 2012, 7, e53027. [CrossRef]

50. Kasai, F.; O’Brien, P.C.M.; Martin, S.; Ferguson-Smith, M.A. Extensive homology of chicken macrochromosomes in the karyotypes of Trachemys scripta elegans and Crocodylus niloticus revealed by chromosome painting despite long divergence times. Cytogenet. Genome Res. 2012, 136, 303-307. [CrossRef] [PubMed]

51. Oliveira, V.C.S.; Viana, P.F.; Gross, M.C.; Feldberg, E.; Da Silveira, R.; Cioffi, M.B.; Bertollo, L.A.C.; Schneider, C.H. Looking for genetic effects of polluted anthropized environments on Caiman crocodilus crocodilus (Reptilia, Crocodylia): A comparative genotoxic and chromosomal analysis. Ecotoxicol. Environ. Saf. 2021, 209, 111835. [CrossRef]

52. Olmo, E.; Signorino, G.G. Chromorep: A Reptile Chromosomes Database. Available online: http://chromorep.univpm.it/?q= node/13 (accessed on 24 August 2020).

53. Degrandi, T.M.; Gunski, R.J.; Garnero, A.V.; Oliveira, E.H.C.; Kretschmer, R.; Souza, M.S.; Barcellos, S.A.; Hass, I. The distribution of $45 \mathrm{~S}$ rDNA sites in bird suggests multiple evolutionary histories. Genet. Mol. Biol. 2020, 43, e20180331. [CrossRef]

54. Amavet, P.; Markariani, R.; Fenocchio, A. Comparative cytogenetic analysis of the South American alligators Caiman latirostris and Caiman yacare (Reptilia, Alligatoridae) from Argentina. Caryologia 2003, 56, 489-493. [CrossRef]

55. Valenzuela, N. Temperature dependent sex determination in reptiles. In Reptilian Incubation: Environment $\mathcal{E}$ Behaviour, 1st ed.; Deeming, D.C., Ed.; Nottinghan University Press: Nottingham, UK, 2004; Volume 1, pp. 65-80. 
56. González, E.J.; Martínez-López, M.; Morales-Garduza, M.A.; García-Morales, R.; Charruau, P.; Gallardo-Cruz, J.A. The sexdetermination pattern in crocodilians: A systematic review of three decades of research. J. Anim. Ecol. 2019, 88, 1417-1427. [CrossRef]

57. Viana, P.F.; Ribeiro, L.B.; Lima, T.; de Carvalho, V.T.; Vogt, R.C.; Gross, M.C.; Feldberg, E. An optimized protocol for obtaining mitotic chromosomes from cultured reptilian lymphocytes. Nucleus 2016, 59, 191-195. [CrossRef]

58. Johnson Pokorná, M.; Altmanová, M.; Rovatsos, M.; Velenský, P.; Vodička, R.; Rehák, I.; Kratochvíl, L. First description of the karyotype and sex chromosomes in the Komodo dragon (Varanus komodoensis). Cytogenet. Genome Res. 2016, 148, 284-291. [CrossRef] [PubMed]

59. Sumner, A.T. A simple technique for demonstrating centromeric heterochromatin. Exp. Cell Res. 1972, 75, 304-306. [CrossRef]

60. Schmid, M. Chromosome banding in Amphibia. IV. Differentiation of GC and AT-rich regions in Anura. Chromosoma 1980, 77, 83-103. [CrossRef] [PubMed]

61. Cioffi, M.B.; Martins, C.; Bertollo, L.A.C. Comparative chromosome mapping of repetitive sequences. Implications for genomic evolution in the fish, Hoplias malabaricus. BMC Genet. 2009, 10, 34. [CrossRef] [PubMed]

62. Ijdo, J.W.; Wells, R.A.; Baldini, A.; Reeders, S.T. Improved telomere detection using a telomere repeat probe (TTAGGG)n generated by PCR. Nucleic Acids Res. 1991, 19, 4780. [CrossRef]

63. Kubat, Z.; Hobza, R.; Vyskot, B.; Kejnovsky, E. Microsatellite accumulation on the Y chromosome in Silene latifolia. Genome 2008, 51, 350-356. [CrossRef]

64. Yano, C.F.; Bertollo, L.A.C.; Cioffi, M.B. Fish-FISH: Molecular Cytogenetics in Fish Species. In Fluorescence In Situ Hybridization (FISH)_Application Guide, 2nd ed.; Liehr, T., Ed.; Springer: Berlin, Germany, 2017; Volume 1, pp. 429-444. [CrossRef]

65. Kosyakova, N.; Liehr, T.; Al-Rikabi, A. FISH-microdissection. In Fluorescence In Situ Hybridization (FISH)—Application Guide, 2nd ed.; Liehr, T., Ed.; Springer: Berlin, Germany, 2017; Volume 1, pp. 81-99. [CrossRef]

66. Sambrook, J.; Russell, D.W. Molecular Cloning, A Laboratory Manual, 3rd ed.; Cold Spring Harbor Laboratory Press: New York, NY, USA, 2001; pp. 58-63.

67. Zwick, M.S.; Hanson, R.E.; McKnight, T.D.; Islam-Faridi, M.N.; Stelly, D.M.; Wing, R.A.; Price, H.J. A rapid procedure for the isolation of C0t-1 DNA from plants. Genome 1997, 40, 138-142. [CrossRef]

68. Symonová, R.; Sember, A.; Majtánová, Z.; Ráb, P. Characterization of fish genomes by GISH and CGH. In Fish Cytogenetic Techniques Ray-Fin Fishes Chondrichthyans, 1st ed.; Ozouf-Costaz, C., Pisano, E., Foresti, F., Toledo, L.F.A., Eds.; CCR Press: Boca Raton, FL, USA, 2015; pp. 118-131.

69. Levan, A.; Fredga, K.; Sandberg, A.A. Nomenclature for centromeric position on chromosomes. Hereditas 1964, 52, 201-220. [CrossRef]

70. Matthey, R.; van Brink, J.M. Sex chromosomes in Amniota. Evolution 1957, 11, 163-165. [CrossRef]

71. Ohno, S. Sex Chromosomes and Sex-linked Genes. In Monographs on Endocrinology, 1st ed.; Labhart, A., Mann, T., Samuels, L.T., Zander, J., Eds.; Springer: Berlin, Germany; New York, NY, USA, 1967; Volume 1, pp. 33-46. [CrossRef]

72. Beçak, W.; Beçak, M.L. Order: CROCODILIA, Suborder: EUSUCHIA, Family: CROCODYLIDAE, Caiman crocodilus (Linnaeus). Folio R-15 1971, 1, 1-3.

73. Olmo, E.A. Reptilia. In Animal Cytogenetics. Chordata 3, 1st ed.; John, B., Ed.; Gebrueder Borntraeger: Berlin, Germany; Stuttgart, Germany, 1986; Volume 4, pp. 1-100.

74. Amavet, P.; Siroski, P.; Donayo, P.; Medina, M. Karyotype of Caiman latirostris and Caiman yacare (Reptilia, Alligatoridae). In Proceedings of the 15th Working Meeting of the Crocodile Specialist Group, Varadero, Cuba, 17-20 January 2000; pp. 135-138.

75. Alfaro, M.E.; Santini, F.; Brock, C.; Alamillo, H.; Dornburg, A.; Rabosky, D.L.; Carnevale, G.; Harmon, L.J. Nine exceptional radiations plus high turnover explain species diversity in jawed vertebrates. Proc. Natl. Acad. Sci. USA 2009, 106, 13410-13414. [CrossRef]

76. Jetz, W.; Thomas, G.H.; Joy, J.B.; Hartmann, K.; Mooers, A.O. The global diversity of birds in space and time. Nature 2012, 491, 444-448. [CrossRef]

77. Pyron, R.A.; Burbrink, F.T.; Wiens, J.J. A phylogeny and revised classification of Squamata, including 4161 species of lizards and snakes. BMC Evol. Biol. 2013, 13, 93. [CrossRef]

78. Bista, B.; Valenzuela, N. Turtle insights into the evolution of the reptilian karyotype and the genomic architecture of sex determination. Genes 2020, 11, 416. [CrossRef] [PubMed]

79. Rovatsos, M.; Altmanová, M.; Johnson Pokorná, M.; Velenský, P.; Baca, A.S.; Kratochvíl, L. Evolution of karyotypes in chameleons Genes 2017, 8, 382. [CrossRef] [PubMed]

80. Müller, J.; Reisz, R.R. Four well-constrained calibration points from the vertebrate fossil record for molecular clock estimates. BioEssays 2005, 27, 1069-1075. [CrossRef] [PubMed]

81. Slijepcevic, P. Telomere length and telomere-centromere relationships? Mutat. Res. 1998, 404, 215-220. [CrossRef]

82. Porter, C.A.; Haiduk, M.W.; de Queiroz, K. Evolution and phylogenetic significance of ribosomal gene location in chromosomes of squamate reptiles. Copeia 1994, 1994, 302-313. [CrossRef]

83. Sochorová, J.; Garcia, S.; Gálvez, F.; Symonová, R.; Kovařík, A. Evolutionary trends in animal ribosomal DNA loci: Introduction to a new online database. Chromosoma 2018, 127, 141-150. [CrossRef] [PubMed]

84. Camper, J.D.; Hanks, B. Variation in the nucleolus organizer region among new world snakes. J. Herpetol. 1995, $29,468-471$. [CrossRef] 
85. O'Meally, S.; Patel, H.R.; Stiglec, R.; Sarre, S.D.; Georges, A.; Graves, J.A.M.; Ezaz, T. Non-homologous sex chromosomes of birds and snakes share repetitive sequences. Chromosome Res. 2010, 18, 787-800. [CrossRef] [PubMed]

86. Rovatsos, M.; Altmanová, M.; Augstenová, B.; Mazzoleni, S.; Velenský, P.; Kratochvíl, L. ZZ/ZW sex determination with multiple neo-sex chromosomes is common in Madagascan chameleons of the genus Furcifer (Reptilia: Chamaeleonidae). Genes 2019, 10, 1020. [CrossRef]

87. Mazzoleni, S.; Augstenová, B.; Clemente, L.; Auer, M.; Fritz, U.; Praschag, P.; Protiva, T.; Velenský, P.; Kratochvíl, L.; Rovatsos, M. Sex is determined by XX/XY sex chromosomes in Australasian side-necked turtles (Testudines: Chelidae). Sci. Rep. 2020, 10, 4276. [CrossRef]

88. Perry, B.W.; Schield, D.R.; Adams, R.H.; Castoe, T.A. Microchromosomes exhibit distinct features of vertebrate chromosome structure and function with underappreciated ramifications for genome evolution. Mol. Biol. Evol. 2021, 38, 904-910. [CrossRef]

89. Burt, D.W. Origin and evolution of avian microchromosomes. Cytogenet. Genome Res. 2002, 96, 97-112. [CrossRef]

90. Norris, T.B.; Rickards, G.K.; Daugherty, C.H. Chromosomes of tuatara, Sphenodon, a chromosome heteromorphism and an archaic reptilian karyotype. Cytogenet. Genome Res. 2004, 105, 93-99. [CrossRef] [PubMed]

91. Auer, H.; Mayr, B.; Lambrou, M.; Schleger, W. An extended chicken karyotype, including the NOR chromosome. Cytogenet. Cell Genet. 1987, 45, 218-221. [CrossRef] [PubMed]

92. McQueen, H.A.; Siriaco, G.; Bird, A.P. Chicken microchromosomes are hyperacetylated, early replicating, and gene rich. Genome Res. 1998, 8, 621-630. [CrossRef]

93. Smith, J.; Bruley, C.K.; Paton, I.R.; Dunn, I.; Jones, C.T.; Windsor, D.; Morrice, D.R.; Law, A.S.; Masabanda, J.; Sazanov, A.; et al. Differences in gene density on chicken macrochromosomes and microchromosomes. Anim. Genet. 2000, 31, 96-103. [CrossRef] [PubMed]

94. Andreozzi, L.; Federico, C.; Motta, S.; Saccone, S.; Sazanova, A.L.; Sazanov, A.A.; Smirnov, A.F.; Galkina, S.A.; Lukina, N.A.; Rodionov, A.V.; et al. Compositional mapping of chicken chromosomes and identification of the gene-richest regions. Chromosome Res. 2001, 9, 521-532. [CrossRef]

95. Kuraku, S.; Ishijima, J.; Nishida-Umehara, C.; Agata, K.; Kuratani, S.; Matsuda, Y. cDNA-based gene mapping and GC 3 profiling in the soft-shelled turtle suggest a chromosomal size-dependent GC bias shared by sauropsids. Chromosome Res. 2006, 14, 187-202. [CrossRef]

96. Olmo, E. Rate of chromosome changes and speciation in reptiles. Genetica 2005, 125, 185-203. [CrossRef]

97. Shedlock, A.M.; Botka, C.W.; Zhao, S.; Shetty, J.; Zhang, T.; Liu, J.S.; Deschavanne, P.J.; Edwards, S.V. Phylogenomics of nonavian reptiles and the structure of the ancestral amniote genome. Proc. Natl. Acad. Sci. USA 2007, 104, 2767-2772. [CrossRef]

98. Alföldi, J.; Di Palma, F.; Grabherr, M.; Williams, C.; Kong, L.; Mauceli, E.; Russell, P.; Lowe, C.B.; Glor, R.E.; Jaffe, J.D.; et al. The genome of the green anole lizard and a comparative analysis with birds and mammals. Nature 2011, 477, 587-591. [CrossRef] [PubMed]

99. Adams, R.H.; Blackmon, H.; Reyes-Velasco, J.; Schield, D.R.; Card, D.C.; Andrew, A.L.; Waynewood, N.; Castoe, T.A. Microsatellite landscape evolutionary dynamics across 450 million years of vertebrate genome evolution. Genome 2016, 59, 295-310. [CrossRef]

100. Kapusta, A.; Suh, A.; Feschotte, C. Dynamics of genome size evolution in birds and mammals. Proc. Natl. Acad. Sci. USA 2017, 114, 1-10. [CrossRef] [PubMed]

101. Balaresque, P.; King, T.E.; Parkin, E.J.; Heyer, E.; Carvalho-Silva, D.; Kraaijenbrink, T.; de Knijff, P.; Tyler-Smith, C.; Jobling, M.A. Gene conversion violates the stepwise mutation model for microsatellites in Y-chromosomal palindromic repeats. Hum. Mutat. 2014, 35, 609-617. [CrossRef] [PubMed]

102. Ramsay, L.; Macaulay, M.; Cardle, L.; Morgante, M.; Ivanissevich, S.d.; Maestri, E.; Powell, W.; Waugh, R. Intimate association of microsatellite repeats with retrotransposons and other dispersed repetitive elements in barley. Plant. J. 1999, 17, 415-425. [CrossRef] [PubMed]

103. Cordaux, R.; Batzer, M.A. The impact of retrotransposon on human genome evolution. Nat. Rev. Genet. 2009, 10, 691-703. [CrossRef]

104. Janes, D.E.; Organ, C.L.; Fujita, M.K.; Shedlock, A.M.; Edwards, S.V. Genome evolution in reptilia, the sister group of mammals. Annu. Rev. Genom. Hum. Genet. 2010, 11, 239-264. [CrossRef] [PubMed]

105. Figliuolo, V.S.P.; Goll, L.; Viana, P.F.; Feldberg, E.; Gross, M.C. First record on sex chromosomes in a species of the family Cynodontidae: Cynodon gibbus (Agassiz, 1829). Cytogenet Genome Res. 2020, 160, 29-37. [CrossRef]

106. Pasquesi, G.I.M.; Adams, R.H.; Card, D.C.; Schield, D.R.; Corbin, A.B.; Perry, B.W.; Reyes-Velasco, J.; Ruggiero, R.P.; Vandewege, M.W.; Shortt, J.A.; et al. Squamate reptiles challenge paradigms of genomic repeat element evolution set by birds and mammals. Nat. Commun. 2018, 9, 2774. [CrossRef]

107. Ahmad, S.F.; Singchat, W.; Jehangir, M.; Suntronpong, A.; Panthum, T.; Malaivijitnond, M.; Srikulnath, K. Dark matter of primate genomes: Satellite DNA repeats and their evolutionary dynamics. Cells 2020, 9, 2714. [CrossRef] [PubMed]

108. Lim, K.Y.; Kovarik, A.; Matyasek, R.; Chase, M.W.; Clarkson, J.J.; Grandbastien, M.A.; Leitch, A.R. Sequence of events leading to near-complete genome turnover in allopolyploid Nicotiana within five million years. New Phytol. 2007, 175, 756-763. [CrossRef] [PubMed]

109. Majka, J.; Majka, M.; Kwiatek, M.; Wiśniewska, H. Similarities and differences in the nuclear genome organization within Pooideae species revealed by comparative genomic in situ hybridization (GISH). J. Appl. Genet. 2017, 58, 151-161. [CrossRef] 
110. Barby, F.F.; Bertollo, L.A.C.; de Oliveira, E.A.; Yano, C.F.; Hatanaka, T.; Ráb, P.; Sember, A.; Ezaz, T.; Artoni, R.F.; Liehr, T.; et al. Emerging patterns of genome organization in Notopteridae species (Teleostei, Osteoglossiformes) as revealed by Zoo-FISH and Comparative Genomic Hybridization (CGH). Sci. Rep. 2019, 9, 1112. [CrossRef] [PubMed]

111. Matsuoka, M.P.; Gharrett, A.J.; Wilmot, R.L.; Smoker, W.W. Genetic linkage mapping of allozyme loci in even- and odd-year pink salmon (Oncorhynchus gorbuscha). J. Hered. 2004, 95, 421-429. [CrossRef]

112. Mandáková, T.; Joly, S.; Krzywinski, M.; Mummenhoff, K.; Lysak, M.A. Fast diploidization in close mesopolyploid relatives of Arabidopsis. Plant. Cell 2010, 22, 2277-2290. [CrossRef] [PubMed]

113. Bomfleur, B.; Decombeix, A.-L.; Schwendemann, A.B.; Escapa, I.H.; Taylor, E.L.; Taylor, T.N.; McLoughlin, S. Habit and ecology of the petriellales, an unusual group of seed plants from the Triassic of Gondwana. Int. J. Plant. Sci. 2014, 175, 1062-1075. [CrossRef]

114. Samad, M.S.; Biswas, A.; Bakken, L.R.; Clough, T.J.; de Klein, C.A.M.; Richards, K.G.; Lanigan, G.J.; Morales, S.E. Phylogenetic and functional potential links $\mathrm{pH}$ and $\mathrm{N}_{2} \mathrm{O}$ emission in pasture soils. Sci Rep. 2016, 6, 35990. [CrossRef]

115. Sessions, S.K.; Kezer, J. Evolutionary cytogenetics of Bolitoglossine salamanders (Family Plethodontidae). In Amphibian Cytogenetics and Evolution, 1st ed.; Green, D.M., Sessions, S.K., Eds.; San Diego Academic Press: San Diego, CA, USA, 1991; pp. 89-130. [CrossRef]

116. Aprea, G.; Andreone, G.; Capriglione, T.; Odierna, V.; Vences, M. Evidence for a remarkable stasis of chromosome evolution in Malagasy tree-frogs (Boophis: Mantellidae). Ital. J. Zool. 2004, 2, 237-243. [CrossRef]

117. Ellegren, H. Evolutionary stasis: The stable chromosome of birds. Trends Ecol. Evol. 2010, 25, 283-291. [CrossRef] [PubMed]

118. Molina, W.F. Chromosomal changes and stasis in marine fish groups. In Fish Cytogenetics, 1st ed.; Pisano, E., Ozouf-Costaz, C., Foresti, F., Kapoor, B.G., Eds.; CRC Press: Boca Raton, FL, USA, 2007; pp. 69-110. [CrossRef]

119. Gaffaroglu, M.; Majtánová, Z.; Symonová, R.; Pelikánová, S.; Unal, S.; Lajbner, Z.; Ráb, P. Present and future salmonid cytogenetics. Genes 2020, 11, 1462. [CrossRef] [PubMed]

120. Barby, F.F.; Ráb, P.; Lavoué, S.; Ezaz, T.; Bertollo, L.A.C.; Kilian, A.; Maruyama, S.R.; de Oliveira, E.A.; Artoni, R.A.; Santos, M.H. From chromosomes to genome: Insights into the evolutionary relationships and biogeography of Old World knifefishes (Notopteridae; Osteoglossiformes). Genes 2018, 9, 306. [CrossRef]

121. Wake, D.B.; Roth, G.; Wake, M.H. On the problem of stasis in organismal evolution. J. Theor. Biol. 1983, 101, 211-224. [CrossRef]

122. Stockdale, M.T.; Benton, M.J. Environmental drivers of body size evolution in crocodile-line archosaurs. Commun. Biol. 2021, 4, 38. [CrossRef]

123. White, M.J.D. Animal Cytology and Evolution, 3rd ed.; Cambridge University Press: Cambridge, UK, $1973 ;$ p. 468.

124. King, M. Chromosome change and speciation in lizards. In Essays on Evolution and Speciation in Honour of M. J. D., 1st ed.; Atchley, W.R., Woodruff, D.S., Eds.; Cambridge University Press: London, UK, 1981; pp. 262-285.

125. White, M.J.D. Modes of Speciation, 1st ed.; W.R. Freeman and Company: San Francisco, CA, USA, 1978.

126. King, M. Species Evolution: The Role of Chromosome Change, 3rd ed.; Cambridge University Press: Cambridge, UK, $1995 ;$ p. 322.

127. Potter, S.; Bragg, J.G.; Blom, M.P.K.; Deakin, J.E.; Kirkpatrick, M.; Eldridge, M.D.B.; Moritz, C. Chromosomal speciation in the genomics era: Disentangling phylogenetic evolution of rock-wallabies. Front. Genet. 2017, 8, 10. [CrossRef] 